\title{
KONDISI SOSIAL EKONOMI DAN KESEJAHTERAAN PETANI DI PERUMAHAN PENGUNGSI KELURAHAN PANDU KECAMATAN BUNAKEN KOTA MANADO
}

\author{
Virjinia Pangkey \\ Charles R. Ngangi \\ Paulus Adrian Pangemanan
}

\begin{abstract}
This study aims to determine the social and economic conditions in the Village Pandu Bunaken District Manado city. This research was carried out in Pandu Village, Bunaken District, Manado city for 3 months starting from Juny until August 2017 starting from preparation, taking data to preparing research report. Data collection methods in this study using primary data and secondary data. Primary data obtained directly from the source by using questionnaires to 30 farmers respondents who domiciled the research area, while secondary data was obtained from institutions related to the research of the village government Pandu. The results showed that the socio-economic conditions and welfare of farmers in refugee housing belong to category of low level of welfare. *bols*.
\end{abstract}

Keywords: farmer walfare, socio-economic conditions, Sub-District Bunaken, Manado City.

\begin{abstract}
ABSTRAK
Penelitian ini bertujuan untuk mengetahui kondisi sosial ekonomi dan kesejahteraan petani di perumahan pengungsi Kelurahan Pandu Kecamatan Bunaken Kota Manado. Penelitian ini dilaksanakan di Kelurahan Pandu Kecamatan Bunaken Kota Manado selama 3 bulan mulai dari bulan Juni sampai bulan Agustus 2017 mulai dari persiapan, pengambilan data sampai pada penyusunan laporan hasil penelitian. Data yang digunakan dalam penelitian ini adalah data primer dan data sekunder. Data primer diperoleh langsung dari sumbernya dengan menggunakan daftar pertanyaan kepada 30 responden petani yang berdomisili di daerah penelitian. Data sekunder diperoleh dari lembaga yang terkait dengan penelitian yaitu pemerintah Keluruhan Pandu. Data dianalisis dengan menggunakan analisis deskriptif. Hasil penelitian menunjukkan bahwa kondisi sosial ekonomi dan kesejahteraan petani di perumahan pengungsi tergolong dalam kategori tingkat kesejahteraan yang rendah. *bols*.
\end{abstract}

Kata kunci: kesejahteraan petani, kondisi sosial ekonomi, Kecamatan Bunaken, Kota Manado.

\section{PENDAHULUAN}

\section{Latar Belakang}

Indonesia merupakan salah satu Negara berkembang dengan sektor pertanian sebagai sumber mata pencaharian dari mayoritas penduduknya. Dengan demikian sebagian besar penduduknya menggantungkan hidupnya pada sektor pertanian. Sebagian besar penggunaan lahan di Indonesia diperuntukkan sebagai lahan pertanian serta hampir 50\% dari total anggkatan kerja menggantungkan nasibnya bekerja di sektor ini (Siswono, 2004).

Perjalanan pembangunan pertanian Indonesia hingga saat ini masih belum dapat menunjukkan hasil yang maksimal jika dilihat 
dari tingkat kesejahteraan petani dan kontribusinya pada pendapatan nasional. Pembangunan pertanian di Indonesia dianggap penting dari keseluruhan pembangunan nasional. Ada beberapa hal yang mendasari mengapa pembangunan pertanian di Indonesia mempunyai peranan penting, antara lain: potensi Sumber Daya Alam yang besar dan beragam, pangsa terhadap pendapatan nasional yang cukup besar, besarnya pangsa terhadap ekspor nasional, besarnya penduduk Indonesia yang menggantungkan hidupnya pada sektor ini, perannya dalam penyediaan pangan masyarakat dan menjadi basis pertumbuhan di pedesaan (Arsyad, 2009).

Potensi pertanian Indonesia yang besar namun pada kenyataannya sampai saat ini sebagian besar dari petani kita masih banyak yang termasuk golongan miskin. Hal ini mengindikasikan bahwa pemerintah pada masa lalu bukan saja kurang memberdayakan petani tapi juga terhadap sektor pertanian keseluruhan. Proses-proses pembangunan hendaknya tidak mengabaikan realitas sosial ekonomi yang dalam menciptakan pemerataan pembangunan di semua wilayah.

Kota Manado sebagai pusat perdagangan dan jasa di Sulawesi Utara telah mengalami perkembangan yang cukup pesat. Perkembangan yang pesat ini selain disebabkan oleh kegiatan pembangunan wilayah perkotaan, juga disebabkan oleh perkembangan jumlah penduduk kota. Pertumbuhan penduduk dapat terjadi secara alami atau kelahiran melebihi kematian dan melalui net migration, in migrants melebihi out migrants. Net migration berupa faktor yang hanya berlaku dalam area lokal (Rantung, 2016).

Kota Manado menjadi daya tarik kuat bagi penduduk desa dan daerah tetangga sebagai kota tujuan migran, karena Manado selain sebagai pusat pemerintahan Sulawesi Utara juga sebagai pusat pendidikan dan pusat perdagangan dan industri.

Perkembangan Kota Manado telah terjadi juga di Kelurahan Pandu Kecamatan Bunaken. Di Kelurahan Pandu sejak tahun 2000 terdapat lokasi perumahan pemukiman dengan lahan bekas Hak Guna Usaha (HGU) yang ditempati pengungsi. Asal usul pengungsi berasal dari
Maluku dan Maluku Utara. Dalam perkembangannya, penduduk yang ada di perumahan tersebut sekarang sudah bertambah dari berbagai daerah bukan hanya dari Maluku ataupun Maluku Utara.

Di kelurahan Pandu terdapat 8 (delapan) lingkungan dan yang berlokasi pada lahan Hak Guna Usaha di Kelurahan Pandu yaitu pada Lingkungan VI, Lingkungan VII, dan Lingkungan VIII.

Penduduk di perumahan pengungsi mempunyai mata pencarian yang berbedabeda sesuai dengan keberadaan hidup mereka, dan kemampuan dalam bertahan hidup. Untuk itu perlu informasi dan gambaran umum tentang kondisi sosial ekonomi petani di daerah perumahan pengungsi tersebut.

\section{Perumusan Masalah}

Berdasarkan latar belakang yang telah dikemukakan, maka yang menjadi masalah dalam penelitian ini yaitu untuk melihat Kondisi Sosial Ekonomi dan Kesejahteraan Petani yang ada di perumahan pengungsi Kelurahan Pandu Kecamatan Bunaken Kota Manado.

\section{Tujuan Penelitian}

Penelitian ini bertujuan untuk mendeskripsikan tentang Kondisi Sosial Ekonomi dan Kesejahteraan Petani di Perumahan Pengungsi Kelurahan Pandu Kecamatan Bunaken Kota Manado.

\section{Manfaat Penelitian}

Dengan adanya penelitian ini diharapkan dapat memberikan

1. Bahan masukan bagi pihak pemerintah dalam usaha meningkatkan kesejahteraan masyarakat dalam merumuskan kebijakan pembangunan yang dapat meningkatkan kesejahteraan ekonomi masyarakat, dan pengembangan masyarakat.

2. Bagi peneliti, sebagai pengetahuan dalam mempelajari teori dan konsep pengembangan masyarakat yang dipelajari selama studi dan sebagai bahan referensi bagi peneliti lain, yang berminat dalam bidang pengembangan masyarakat. 


\section{METODOLOGI PENELITIAN}

\section{Waktu dan Tempat Penelitian}

Penelitian ini dilaksanakan dari bulan Juni sampai bulan April 2017 mulai dari persiapan, pengambilan data sampai penyusunan laporan dan ujian sarjana. Tempat penelitian di Perumahan Pengungsi Kelurahan Pandu Kecamatan Bunaken Kota Manado.

\section{Metode Pengumpulan Data}

Data yang diperlukan dalam penelitian ini yaitu data primer dan data sekunder. Data primer diperoleh melalui wawancara dengan Kepala Keluarga yang menjadi sampel dalam penelitian ini. Wawancara dilakukan dengan menggunakan daftar pertanyaan yang telah disiapkan terlebih dahulu. Pertanyaan terdiri dari pertanyaan terbuka dan pertanyaan tertutup tentang keadaan sosial ekonomi rumah tangga petani. Data sekunder diperoleh melalui dokumen dan hasil penelitian kepustakaan serta data dan informasi yang berada di Kantor Kelurahan Pandu Kecamatan Bunaken Kota Manado serta instansi yang terkait dengan permasalahan penelitian.

\section{Metode Pengambilan Sampel}

Populasi dari penelitian ini adalah petani di Kelurahan Pandu, Kecamatan Bunaken. Responden yang diambil adalah petani yang berdomisili pada lingkungan VI, VII, dan VIII.

Pemilihan responden dilakukan dengan teknik pengambilan sampel secara sengaja (purposive sampling). Dalam hal ini sampel yang diambil berjumlah 30 orang petani responden. Angka 30 diambil dari standart minimal penelitian survey yaitu berdasarkan asumsi bahwa populasi yang diambil memiliki sebaran normal.

Dalam mengkaji keadaan sosial ekonomi masyarakat petani diperlukan kegiatan di bidang pertanian. Keadaan kesejahteraan terlihat dari bentuk keadaan ekonomi dan non ekonomi yang dinikmati oleh responden.

\section{Konsepsi Pengukuran Variabel}

Gambaran serta keadaan/kondisi nyata pada keadaan petani dilihat dari ukuran tingakatan pengukuran dari BPS (Badan Pusat Statistik) sehingga mempermudah dalam mempresentaskan data.

Indikator penelitan yang dikaji dalam penelitian ini :

1. Karakteristik Responden

1) Umur Responden

2) Jenis Kelamin

3) Jumlah Tanggungan

2. Indikator Kesejahteraan Berdasarkan BPS

A. Kependudukan

1) Skor1 : Usia Tidak Produktif

2) Skor 2 : Usia Belum Produktif

3) Skor 3: Usia Produktif

B. Kesehatan

1) Skor 1: Kebanyakan Sakit / Kurang

2) Skor $2:$ Beberapa Sakit / Cukup

3) Skor 3: Sehat Semua / Baik

C. Pendidikan
1) Skor 1: Mudah
2) Skor $2:$ Cukup
3) Skor 3: Sulit

D. Ketenagakerjaan

1) Skor $1:$ Kurang dari 1 Jam/Minggu

2) Skor $2:$ Antara 1 Jam/Minggu sampai $3 \mathrm{jam} /$ Minggu

3) Skor 3 : Diatas 35 Jam/Minggu

E. Taraf Pola dan Konsumsi

1) Skor $1:(<$ Rp. 1.500.000)

2) Skor 2 : (Antara Rp. 1.500.000 - Rp. 3.000 .000

3) Skor 3: (> Rp. 3.000.000)

F. Perumahan dan Lingkungan

1) Skor 1 : Tidak Permanen, Tidak Bersih dan Tidak Rapi

2) Skor 2 : Semi Permanen, Bersih dan Tidak Rapi

3) Skor 3 : Permanen, Bersih dan Rapi

G. Kemiskinan
1) Skor $1:$ Kurang
2) Skor $2:$ Sedang
3) Skor 3 : Cukup

H. Sosial Lainnya

1) Skor $1:$ Tidak Terpenuhi

2) Skor $2:$ Kurang terpenuhi

3) Skor $3:$ Terpenuhi 


\section{Metode Analisis Data}

Data yang diamati dalam penelitian ini adalah kondisi sosial ekonomi dan kesejahteraan petani di perumahan pengungsi Kelurahan Pandu Kecamatan Bunaken Kota Manado. Gambaran serta keadaan/ kondisi nyata petani, digunakan melalui tabulasi dimana skor responden dijumlahkan dan hitung untuk mendapatkan frekuensi, kemudian dipresentasikan secara deskriptif dan disajikan dalam bentuk tabel.

\section{HASIL DAN PEMBAHASAN}

\section{Deskripsi Wilayah}

\section{Letak Geografis}

Penelitian ini dilakukan di Kelurahan Pandu Kecamatan Bunaken Kota Manado Provinsi Sulawesi Utara. Adapun luas dari Kelurahan Pandu yaitu 159,02 Ha. Kelurahan Pandu berjarak $3 \mathrm{~km}$ dari kecamatan dan 8 km dari pusat Kota Manado. Dari jarak tersebut dapat diasumsikan bahwa kelurahan ini cukup cepat dalam menerima arus informasi yang akan berpengaruh terhadap kemajuan dan perkembangan daerah.

\section{Batas Wilayah}

Batas-batas wilayah di Kelurahan Pandu Kecamatan Bunaken Kota Manado adalah sebagai berikut :

a. Sebelah Utara dengan Desa Wori, Kecamatan Wori Kab. Minut

b. Sebelah Selatan dengan Kelurahan Bengkol Kec. Mapanget Kota Manado

c. Sebelah Timur dengan Kelurahan Bengkol Kec. Mapanget Kota Manado

d. Sebelah Barat dengan Kelurahan Molas Kec. Bunaken Kota Manado

\section{Keadaan Penduduk}

Jumlah penduduk yang ada di Kelurahan Pandu sebanyak 5.604 jiwa, dengan jumlah laki - laki sebanyak 3.041 jiwa dan perempuan sebanyak 2.563 jiwa .

\section{Deskripsi Responden}

Identitas dan karakteristik petani responden terdiri dari 30 anggota petani responden yang berdomisili di perumahan Kelurahan Pandu Kecamatan Bunaken Kota Manado. Responden semuanya merupakan masyarakat migrasi yang berasal dari Maluku dan Maluku Utara yang bermukim di daerah penelitian sejak tahun 2001. Responden sudah tidak kembali lagi ke daerah asal karena beranggapan telah mendapatkan keamanaan dan kenyamanan di daerah tempat bermukim sekarang, ada juga yang berpendapat bahwa tempat tinggal mereka telah diratakan sehingga tidak ada tempat lagi untuk bernaung, dan ada pula yang merasa takut untuk kembali karena mencemaskan jikalau kejadian tersebut terjadi kembali.

\section{Umur Responden}

Umur mempengaruhi kemampuan seseorang dalam melakukan suatu aktivitas dalam bertindak maupun dalam konsep berpikir. Tabel1 menunjukkan umur responden petani dalam penelitian ini.

\section{Tabel 1. Umur Responden Penelitian}

\begin{tabular}{cccc}
\hline No & $\begin{array}{c}\text { Umur Responden } \\
\text { (Tahun) }\end{array}$ & Jumlah & Persentase (\%) \\
\hline 1 & $46-55$ & 9 & 30 \\
2 & $56-65$ & 16 & 53.33 \\
3 & $>66$ & 5 & 16.67 \\
\hline & Jumlah & $\mathbf{3 0}$ & $\mathbf{1 0 0}$ \\
\hline
\end{tabular}

Tabel 1. menunjukkan bahwa kisaran usia terbanyak 56 - 65 tahun sebanyak 16 orang dengan presentasi $53.33 \%$, dan diikuti oleh kisaran usia 46 - 55 tahun sebanyak 9 orang responden dengan presentasi $30 \%$. Pada tabel diatas dapat dilihat pula bahwa berdapat $16.66 \%$ dari total jumlah responden atau sebanyak 5 orang responden berumur di atas 66 tahun. Hal ini menunjukkan bahwa di Perumahan pengungsi Kelurahan Pandu Kecamatan Bunaken Kota Manado terdapat tenaga kerja dalam usaha tani yang berada pada usia produktif dan tidak produktif lagi. 


\section{Jenis Kelamin}

Jenis kelamin responden yang menjadi sampel dalam penelitian ini adalah $100 \%$ berjenis kelamin laki-laki, tetapi juga ada petani berjenis kelamin perempuan sesuai dengan data yang diperoleh dari kepala lingkungan lokasi penelitian. Hal ini menunjukkan bahwa budidaya tidak hanya dilakukan oleh laki-laki tetapi juga perempuan. Petani yang jenis kelamin perempuan tidak masuk dalam kriteria sampel yang diambil.

\section{Jumlah Tanggungan}

Jumlah anggota keluarga pada setiap rumah tangga responden memberikan gambaran mengenai ketersediaan tenaga kerja, tanggungan hidup keluarga dan besarnya pendapatan keluarga. Jumlah tanggungan keluarga dapat mempengaruhi semangat dan kreatifitas kepala keluarga dalam memenuhi kebutuhan hidup keluarganya. Tabel 2 menunjukkan jumlah tanggungan responden yang berada di perumahan pengungsi.

\begin{tabular}{cccc}
\multicolumn{4}{c}{ Tabel 2. Jumlah Tanggungan Kepala Keluarga } \\
\hline No. & Kriteria & Jumlah & Persentase (\%) \\
\hline 1 & $>4$ Orang & 1 & 3.3 \\
2 & 4 Orang & 6 & 20 \\
3 & $<4$ Orang & 23 & 76.7 \\
\hline & Jumlah & $\mathbf{3 0}$ & $\mathbf{1 0 0}$
\end{tabular}

Data pada Tabel 2 diatas menunjukkan bahwa jumlah anggota kurang dari empat jiwa sebanyak 23 responden $(76,7 \%)$, jumlah anggota keluarga dengan empat jiwa sebanyak 6 reponden (20\%), dan jumlah anggota keluarga lebih dari empat orang sebanyak 1 responden $(3.3 \%)$.

Jumlah tanggungan keluarga ini ratarata berjumlah tiga orang, artinya satu kepala keluarga petani harus bekerja untuk memenuhi kebutuhan hidup empat orang anggota keluarga. Namun apabila anggota keluarga dimanfaatkan dengan optimal, keluarga yang besar merupakan sumber tenaga kerja potensial yang dapat meringankan beban kepala keluarga.
Tingkat Kesejahteraan Petani

Berikut ini disajikan tingkat kesejahteraan petani berdasarkan masing-masing indikator dari 8 indikator menurut Badan Pusat Statistik (BPS), 2010 berdasarkan temuan di lapangan.

\section{Kependudukan}

Penduduk merupakan modal dasar dalam pembangunan suatu negara, tetapi di sisi lain penduduk juga dapat menjadi suatu beban bagi negara untuk mencapai pertumbuhan ekonomi. Kesejahteraan yang diukur berdasarkan indikator kependudukan dilihat dari jumlah penduduk berusia belum produktif, usia produktif dan tidak produktif. Keadaan kesejateraan berdasarkan indukator kependudukan ditunjukkan pada Tabel 3.

\begin{tabular}{clcc}
\multicolumn{3}{c}{ Tabel 3. } & Kesejahteraan Berdasarkan Indikator Kependudukan \\
\hline No. & Kriteria & Jumlah & Persentase (\%) \\
\hline 1 & Produktif & 9 & 30.00 \\
2 & Belum Produktif & 10 & 33.33 \\
3 & Tidak Produktif & 11 & 36.67 \\
\hline & Jumlah & $\mathbf{3 0}$ & $\mathbf{1 0 0}$ \\
\hline
\end{tabular}

Tabel 3 menunjukkan bahwa dalam keluarga responden berada pada kisaran usia produktif yaitu sebanyak 9 responden dengan presentase $30 \%$. Kemudian di ikuti dengan kisaran usia belum produktif sebanyak 9 responden atau $33.33 \%$ selebihnya dengan kisaran usia yang sudah tidak produktif lagi sebanyak 11 responden dengan presentase $36.67 \%$. Hal ini menunjukkan bahwa di Perumahan Pengungsi di kelurahan Pandu terdapat tenaga kerja dalam usaha tani yang berusia produktif dan pada usia yang tidak produktif lagi.

\section{Kesehatan}

Tingkat kualitas kesehatan merupakan indikator penting untuk menggambarkan mutu pembangunan manusia suatu wilayah. Semakin sehat kondisi suatu masyarakat, maka akan semakin mendukung proses dan dinamika pembangunan ekonomi suatu negara/wilayah semakin baik. Pada akhirnya hasil dari kegiatan perekonomian adalah tingkat produktivitas penduduk suatu wilayah dapat diwujudkan, bahkan dengan tingkat produktivitas yang tinggi. 
Tabel 4. Kesejateraan Berdasarkan Indikator Kesehatan dan

\begin{tabular}{|c|c|c|c|}
\hline \multicolumn{4}{|c|}{ Gizi } \\
\hline No. & Kriteria & Jumlah & Persentase (\%) \\
\hline 1 & Bagus & 14 & 46.67 \\
\hline 2 & Cukup & 11 & 36.67 \\
\hline 3 & Kurang & 5 & 16.67 \\
\hline & Jumlah & 30 & 100 \\
\hline
\end{tabular}

Dalam Tabel 4 terdapat 14 responden dalam kriteria Bagus dengan presentase 46.67\%, Cukup 11 responden atau $36.67 \%$ dan Kurang dengan presentase $16.67 \%$ sebanyak 5 responden. Tingkat kesehatan merupakan salah satu indikator produktivitas. Kesehatan merupakan faktor yang mendukung petani dalam beraktifitas untuk melakukan kegiatan pertanian. Jika masyarakat memiliki kesehatan yang baik maka tingkat kinerjanya akan baik, begitu pula sebaliknya. Berdasarkan hasil pengamatan dilapangan responden memiliki kondisi yang prima atau pada kategori tingkat kesehatan yang baik untuk melakukan kegiatan pertanian.

Kondisi kesehatan yang prima pada petani responden dikarenakan setiap hari para petani melakukan kegiatan yang menguras tenaga, sehingga para petani responden jarang sakit, sedangkan petani responden yang memiliki kondisi yang kurang prima dikarenakan usia sehingga daya tahan tubuh dan energi menurun.

Berdasarkan temuan dilapangan ketercukupan asupan gizi tergolong dalam kategori cukup, karena dalam memenuhi kebutuhan makanan setiap hari petani responden dapat menyediakan makanan empat sehat lima sempurna.

\section{Pendidikan}

Tingkat pendidikan mempengaruhi kemampuan seseorang dalam mengembangkan konsep berpikir maupun dalam mengambil suatu keputusan. Pendidikan petani responden tergolong rendah dengan jumlah responden 14 atau $46.67 \%$ karena hanya sampai menduduki bangku SMP/ Sederajat. Selanjutnya, 33.33\% petani responden atau sebanyak 10 responden dengan indikator Pendidikan yang tinggi dengan mengeyam Pendidikan SMA/ Sederajat.
Sedangkan hanya 6 orang responden atau 20\% dari total responden berada pada tingkat Pendidikan yang rendah yang pernah mengenyam pendidikan setingkat SD.

Berikut tabel yang menunjukkan kriteria kesejahteraan dari keluarga petani berdasarkan indikator Pendidikan dalam rumahtangga.

\begin{tabular}{|c|c|c|c|}
\hline No. & Kriteria & Jumlah & Persentase $(\%)$ \\
\hline 1 & Sulit & 5 & 16.67 \\
\hline 2 & Cukup & 10 & 33.33 \\
\hline \multirow[t]{2}{*}{3} & Mudah & 15 & 50 \\
\hline & Jumlah & 30 & 100 \\
\hline
\end{tabular}

Indikator Pendidikan untuk kesejahteraan yang diukur pada keluarga petani yang ditunjukkan pada Tabel 5 berdasarkan akses untuk memperoleh Pendidikan bagi keluarga petani tentang terpenuhinya atau tidak biaya administrasi sebelum masuk sekolah dan selama sekolah. Akses untuk jenjang Pendidikan terakhir yang telah diselesaikan anggota keluarga. terdapat 5 responden $(16.67 \%)$ yang tergolong pada kriteria sulit. Sebagian tergolong dalam kriteria cukup sebanyak 10 responden $(33.33 \%)$ dan mudah sebanyak 15 responden $(50 \%)$.

Secara umum, rumah tangga miskin tidak memiliki kemampuan ekonomi yang mencukupi untuk memenuhi segala kebutuhan hidupnya. Sebagian besar penghasilan atau pendapatan yang dimiliki hanya untuk memenuhi kebutuhan makan sehari-hari. Oleh karena itu, rumah tangga miskin hanya memiliki peluang yang kecil dalam memenuhi kebutuhan pendidikan anak-anaknya. Namun karena kesadaran yang tinggi dari orang tua mengenai pendidikan anak-anaknya erat kaitannya dengan pendidikan dari kepala rumah tangga yang rendah membuat petani responden berusaha untuk menyekolahkan anak-anaknya ke jenjang yang lebih tinggi. Indikator tingkat pendidikan formal menunjukan kualitas sumber daya manusia, di kawasan perumahan pengungsi di dominasi oleh kriteria mudah dikarenakan akses Pendidikan anak petani responden yang dapat sudah dapat dijangkau baik jarak maupun biaya. Sebagian besar anak petani responden sudah tidak bersekolah lagi karena telah menyelesaikan pendidikan 
SMA/Sederajat, ada juga yang masih bersekolah sampai saat ini dengan biaya tanggungan orang tua, dan melanjukan pendidikan ke perguruan tinggi dengan sebagian bantuan dari PPA (Pusat Pengembangan Anak) juga Beasiswa.

\section{Ketenagakerjaan}

Berdasarkan data hasil menunjukkan $100 \%$ responden berprofesi sebagai petani. Pekerjaan dari responden yaitu petani yang mengusahakan berbagai jenis tanaman pertanian dalam menunjang kebutuhan hidup keluarga sehari-hari. Adapun tanaman yang diusahakan oleh petani yaitu, pisang, jagung, pepaya dan tanaman rempah-rempah lainnya.

Selain mempunyai pekerjaan utama, sebagian responden mempunyai mata pencaharian sampingan. Jumlah responden yang mempunyai mata pencaharian sampingan sebanyak 14 responden atau $46.67 \%$ dari 30 total responden. Jenis mata pencaharian sampingan responden bervariasi, yaitu buruh tani/bangunan , pedagang/wiraswasta, beternak dan lainnya. Namun masih banyak pula responden yang hanya mengandalkan pendapatannya dari hasil pertanian sebagai pekerjaan utama dan tidak mempunyai pekerjaan sampingan, yaitu sebanyak 16 responden atau $53.33 \%$. Oleh karena itu perlu pengembangan keterampilan dalam rangka meningkatkan pendapatan masyarakat supaya tidak hanya mengandalkan pendapatan dari usahataninya.

Tenaga kerja yang peroleh untuk mengusahakan pengelolaan pertanian yaitu dari dalam keluarga dan dari luar anggota keluarga. Tenaga kerja luar anggota keluarga dengan menyewa buruh tani dan tenaga kerja dalam keluarga yaitu dengan cara petani responden mengusahakan pengelolaan pertanian di bantu oleh anggota keluarga dan tidak mendapatkan upah/gaji. Hal demikian di lakukan karena ada petani yang mampu menyewa buruh tani untuk membantu kelangsungan pengelolaan lahan pertanian, namun ada juga petani yang tidak mampu menyewa buruh tani sehingga harus mengusahakan kegiatan pertanian sendiri ataupun di bantu anggota keluarga untuk meminimalisir pengeluaran petani responden.

\begin{tabular}{|c|c|c|c|c|}
\hline Tabel & 6. & $\begin{array}{l}\text { Kesejahteraan } \\
\text { Ketenagakerjaan }\end{array}$ & Berdasarkan & Indikator \\
\hline No. & & Kriteria & Jumlah & $\begin{array}{c}\text { Persentase } \\
(\%)\end{array}$ \\
\hline 1 & \multicolumn{2}{|c|}{ Diatas $35 \mathrm{jam} / \mathrm{ming}$ gu } & 6 & 20 \\
\hline 2 & \multicolumn{2}{|c|}{$\begin{array}{l}\text { Antara } 15 \text { jam sampai } 35 \\
\text { jam/minggu }\end{array}$} & 11 & 36.67 \\
\hline 3 & \multicolumn{2}{|c|}{ Kurang dari 15 jam } & 13 & 43.33 \\
\hline & \multicolumn{2}{|c|}{ Jumlah } & 30 & 100 \\
\hline
\end{tabular}

Terkait dengan indikator kesejahteraan berdasarkan ketenagakerjaan keluarga petani dalam hal waktu kerja yang dihabiskan selama seminggu, seorang petani dapat dikategorikan sebagai pekerja dimana mereka bekerja di jam kerja rata-rata selama seminggu (diatas 35 jam), karena seorang pekerja yang dikategorikan sebagai bukan pengangguran adalah mereka yang memiliki jumlah jam kerja normal selama seminggu (minimal 35 jam).

Berdasrkan Tabel 6 menunjukkan indikator ketenagakerjaan dalam keluarga petani bahwa terdapat 6 responden $(20 \%)$ tergolong dalam kategori tinggi karena menggunakkkan waktu kerja diatas 35 jam/ minggu, diikuti dengan 11 responden (36.67\%) tergolong sedang dengan menggunakkan antara $15 \mathrm{jam} /$ minggu sampai $35 \mathrm{jam} /$ minggu. Dan sebanyak 13 responden atau $43.33 \%$ tergolong rendah karena bekerja dengan jam kerja kurang dari 15 jam/ minggu.

Petani yang menggunakkan waktu kerja penuh yakni petani yang hanya mengusahakan pekerjaan di bidang pertanian saja, sedangkan petani yang kurang waktu kerjanya yakni petani yang mempunyai pekerjaan sampingan di luar usahatani.

\section{Taraf Pola dan Konsumsi}

Pola konsumsi rumah tangga merupakan salah satu indikator kesejahteraan rumah tangga/keluarga. Pada Tabel 12 menunjukkan indikator taraf dan pola konsumsi petani di perumahan pengungsi yang diukur berdasarkan kriteria pendapatan dalam Rp/bln, besar kecilnya pendapatan petani mempengaruhi keputusan apa yang akan dikerjakan dan jenis usaha yang akan dilakukannya pada sebidang lahan yang dimilikinya. Kategori pengeluaran kebutuhan untuk konsumsi di banding dengan kebutuhan lain non konsumsi (Pendidikan, 
listrik, air, tabungan, transportasi dll) dalam keluarga serta kategori jumlah pengeluaran untuk konsumsi dalam satu bulan.

Berdasarkan indikator kesejahteraan dari BPS tingkat pendapatan tinggi > Rp.3.000.000, cukup yaitu antara Rp.1.500.000 - sampai Rp.3.000.00, dan rendah < Rp.1.500.000.

\begin{tabular}{|c|c|c|c|}
\hline No. & Kriteria & Jumlah & Persentase $(\%)$ \\
\hline 1 & $>$ Rp. 3.000 .000 & 3 & 10 \\
\hline 2 & $\begin{array}{l}\text { Antara Rp.1.500.000 - } \\
\text { Rp.3.000.000 }\end{array}$ & 13 & 43.33 \\
\hline \multirow[t]{2}{*}{3} & $<$ Rp. 1.500 .000 & 14 & 46.67 \\
\hline & Jumlah & 30 & 100 \\
\hline
\end{tabular}

Tabel 7 menunjukkan tingkat pendapatan petani responden yang tertinggi adalah pendapatan sebanyak < Rp.1.500.000 dengan jumlah responden 14 (46.67\%), diikuti dengan 13 responden yang memiliki tingkat pendapatan antara Rp.1.500.000 sampai Rp.3.000.000 dan 3 responden yang memliki pendapatan > Rp.3.000.000/bulan. Rata-rata tingkat pendapatan responden masih di bawah Upah Minimum Provinsi (UMP) Sulawesi Utara, khususnya Kota Manado yaitu sebesar Rp2.820.000.

\begin{tabular}{clcc}
\multicolumn{4}{l}{ Tabel 8. Pengeluaran Konsumsi Rp/Bulan } \\
\hline No. & \multicolumn{1}{c}{ Kriteria } & Jumlah & Persentase (\%) \\
\hline 1 & $>$ Rp.3.000.000 & 4 & 13.33 \\
2 & Antara Rp.1.500.000- & 15 & 50 \\
& Rp.3.000.000 & 11 & 36.67 \\
\hline & <pp.1.500.000 & $\mathbf{3 0}$ & $\mathbf{1 0 0}$ \\
\hline
\end{tabular}

Tabel 8 menunjukkan pengeluaran petani responden untuk konsumsi di dominasi pengeluaran sebanyak antara Rp.1.500.000 Rp.3.000.000 dengan jumlah responden 15 (\%), kemudian diikuti dengan jumlah pengeluaran < Rp.1.500.000 sebanyak 11 responden atau \%, dan pengeluaran >Rp.3.000.000 sebanyak 4 responden $(\%)$.

Berikut tingkat kesejahteraan berdasarkan Indikator taraf pola dan konsumsi :

Tabel 9. Kesejahteraan Berdasarkan Indikator Taraf dan Pola Konsumsi

\begin{tabular}{clcc}
\multicolumn{3}{c}{ Konsumsi } & \\
\hline No. & Kriteria & Jumlah & Persentase (\%) \\
\hline 1 & Tinggi & 3 & 10.00 \\
2 & Sedang & 18 & 60.00 \\
3 & Rendah & 9 & 30.00 \\
\hline & Jumlah & $\mathbf{3 0}$ & $\mathbf{1 0 0}$ \\
\hline
\end{tabular}

Tabel 9 menunjukkan terdapat 18 responden dengan presentase $60 \%$ mempunyai tingkat kesejahteraan yang sedang berdasarkan indikator taraf dan pola konsumsi dan 3 responden $(10 \%)$ yang tergolong pada katerogi tinggi, sisanya 9 responden (30\%) pada taraf pola dan konsumsi yang rendah.

Untuk memenuhi kebutuhan pangan khususnya bahan pokok, petani responden mendapatakan keringanan dengan bantuan Pemerintah setempat berupa Raskin (Beras Miskin), dan kebutuhan pangan pelengkap petani responden juga menggunakan hasil pertanian yang mereka usahakan, namun ada juga yang membeli di pasar atau pada penjual keliling.

Dalam memenuhi kebutuhan non makanan (sandang) responden membeli pakaian dalam setahun ada yang satu kali, dua kali dan ada juga yang membeli lebih dari tiga kali dalam setahun sepanjang tahun 2017.

Petani responden membeli pakaian sekali dalam setahun biasanya pada hari raya khusus Natal, karena seluruh responden beragama Kristen, petani yang membeli pakaian dua kali dalam setahun dikarenakan memiliki anak yang masih bersekolah sehingga harus membeli seragam untuk menunjang Pendidikan anak respoden dan petani yang membeli pakaian lebih dari tiga kali dalam setahun biasanya karena faktor kebutuhan pakaian yang harus di penuhi.

\section{Perumahan dan Lingkungan}

Manusia sebagai makhluk hidup memiliki kebutuhan-kebutuhan hidup yang harus dipenuhi dalam rangka mempertahankan kelangsungan hidupnya. Berdasarkan tingkat intensitas kebutuhannya, manusia memiliki tiga kebutuhan primer yaitu sandang, pangan, dan papan. Papan atau dapat juga diartikan sebagai tempat tinggal yang dapat menjadi tempat bernaung manusia. Perumahan sebagai salah satu bentuk dari pemukiman, merupakan salah satu kebutuhan manusia yang

paling dasar. Selain sebagai salah satu kebutuhan dasar, rumah dan kelengkapannya merupakan faktor penentu indikator kesejahteraan rakyat. 
Kondisi dan lingkungan tempat tinggal yang layak atau tidak merupakan salah satu indikator tingkat kesejahteraan masyarakat. Berikut ini kategori tingkat kesejahteraan petani di lokasi penelitian perumahan pengungsi di Kelurahan Pandu Kota Manado.

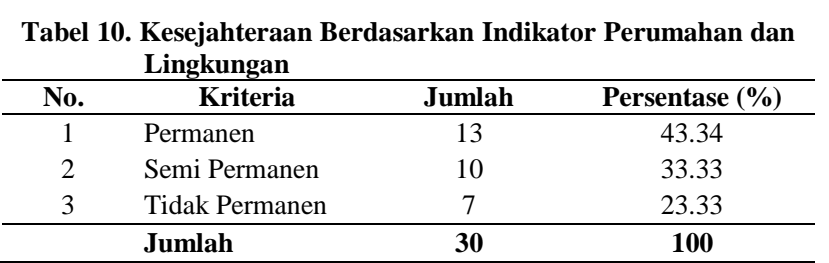

Keseluruhan responden tinggal di kawasan Perumahan Pengungsi yang adalah tanah Hak Guna Usaha (tanah negara) yang di bangun oleh Pemerintah. Tabel 10 menujukkan kondisi rumah yang di tempati oleh responden rata-rata terbuat dari batubata, beratapkan seng dan sudah berlantai bukan tanah lagi (semi permanen) sebanyak 10 responden $(33.33 \%)$ dan 13 petani responden dengan presentase $43.33 \%$ yang telah merenovasi rumah sehingga menjadi rumah permanen meskipun lahan yang di tempati bukan hak milik pribadi. Dan 7 responden dengan presentase $23.33 \%$ memiliki rumah yang tidak permanen karena sejak ditempati jika di perlukan saja merenovasi rumah sehingga adanya ketidaknyamanan petani responden menghuni tempat tinggal tersebut. Karena juga rumah responden berada di kawasan Perumahan pengungsi sehingga untuk luas lahan dan bangunan sama besarnya yaitu $4 \times 6 \mathrm{~m} 2$.

Kualitas dan kenyamanan rumah tinggal juga di tentukan oleh fasilitas suatu rumah tinggal termasuk air bersih dan penerangan. Dikarenakan lahan yang tidak memadai maka sebagian petani responden membuat sumur bor yang tidak memerlukan lahan yang luas. Namun ada juga petani responden yang memiliki sumur. Untuk petani yang tidak memiliki sumur ataupun sumur bor di fasilitasi oleh Pemerintah setempat dengan bantuan PNPM membuat sumur bor dan tampungan air secara umum sehingga mempermudah petani responden dan masyarakat sekitar untuk mendapatkan air bersih demi kelangsungan hidup sehari-hari.
Sumber penerangan yang ada di Perumahan Pengungsi Kelurahan Pandu menggunakan sumber listrik PLN yang sudah difasilitasi oleh Pemerintah bersamaan dengan bangunan yang ada.

\section{Kemiskinan}

Secara umum, rumah tangga miskin tidak memiliki kemampuan ekonomi yang mencukupi untuk memenuhi segala kebutuhan hidupnya. Sebagian besar penghasilan atau pendapatan yang dimiliki hanya untuk memenuhi kebutuhan makan sehari-hari. Oleh karena itu, rumah tangga miskin hanya memiliki peluang yang kecil dalam memenuhi kebutuhan pokok sehari-hari.

Berikut kriteria indikator kemiskinan dalam tingkat kesejahteraan yang diukur dalam penelitian ini berupa pendapatan yang dieroleh dalam memenuhi kebutuhan pokok sehari-hari.

\begin{tabular}{clcc}
\multicolumn{4}{c}{ Tabel 11. Kesejahteraan Berdasarkan Indikator Kemiskinan } \\
\hline No. & Kriteria & Jumlah & Persentase (\%) \\
\hline 1 & Terpenuhi & 0 & - \\
2 & Kurang Terpenuhi & 15 & 50 \\
3 & Tidak Terpenuhi & 15 & 50 \\
\hline & Jumlah & $\mathbf{3 0}$ & $\mathbf{1 0 0}$ \\
\hline
\end{tabular}

Tabel 11 menunjukkan indikator kemiskinan yang diperoleh dari 30 responden petani yaitu pendapatan yang diperoleh hanya cukup untuk memenuhi kebutuhan pokok seharihari. Dalam kategori kurang terpenuhi dan tidak terpenuhi masing-masing 15 responden dengan presentase $50 \%$. Tidak ada yang memenuhi kriteria terpenuhi yaitu yang dapat memenuhi semua kebutuhuan di luar kebutuhan pokok.

Petani responden lebih menerapkan bagaimana dapat bertahan hidup sebagai petani penggarap yang hanya dapat memenuhi kebutuhan pokok sehari-hari dan modal untuk kebutuhan usahatani.

Masalah kemiskinan selalu menjadi prioritas pemerintah dalam menjalankan pembangunan. Penanggulangan kemiskinan memerlukan langkah-langkah penanganan dan pendekatan secara sistematik, terpadu dan komprehensif dari seluruh pihak. Berbagai pihak yang memegang peranan penting dan memiliki tanggung jawab yang sama dalam upaya penanggulangan kemiskinan adalah pemerintah pusat, pemerintah daerah dan dunia usaha (sektor swasta) dan masyarakat. 


\section{Sosial Lainnya}

Indikator lainnya tentang kesejahteraan masyarakat adalah keadaan sosial lainnya berupa kemampuan keluarga dalam memenuhi kebutuhan untuk memperoleh hiburan berupa rekreasi, akses untuk memperoleh informasi melalui media informasi berupa televisi, koran, internet dan akses untuk dapat berkomunikasi menggunakkan media komunikasi berupa telepon/handphone.

Berikut disajikan kriteria kesejateraan berdasarkan indikator sosial lainnya:

\begin{tabular}{clcc}
\multicolumn{4}{c}{ Tabel 12. Kesejahteraan Berdasarkan Indikator Sosial Lainnya } \\
\hline No. & \multicolumn{1}{c}{ Kriteria } & Jumlah & Persentase (\%) \\
\hline 1 & Terpenuhi & 5 & 16.67 \\
2 & Kurang Terpenuhi & 18 & 60.00 \\
3 & Tidak Terpenuhi & 7 & 23.33 \\
\hline & \multirow{2}{*}{ Jumlah } & \multirow{3}{*}{$\mathbf{1 0 0}$}
\end{tabular}

Tabel 12 menunjukkan kategori indikator sosial lainnya berdasarkan temuan dilapangan bahwa terdapat 5 responden $(16.67 \%)$ yang mempunyai indikator sosial tergolong kategori terpenuhi, sebagian besar tergolong pada kategori kurang terpehuni sebanyak 18 responden dengan presentase $60 \%$ dan 7 responden tergolong pada kategori rendah sebanyak 7 responden $(23.33 \%)$.

Kebutuhan untuk rekreasi atau perjalanan wisata dapat menjadi salah satu indikator sosial yang menandakan kesejahteraan masyarakat. Semakin tinggi tingkat kesejahteraan masyarakat, gaya hidup masyarakat juga cenderung berubah dengan melakukan pemenuhan kebutuhan tersier yang salah satunya adalah berwisata. Tujuan melakukan perjalanan wisata biasanya untuk relaksasi, menikmati hari libur, menikmati pemandangan alam dan lain-lain. Menurut wawancara yang telah dilakukan, petani reponden kurang melakukan perjalanan wisata. Perjalanan wisata dilakukan petani responden karena adanya kegiatan bersama bukan karena inisiatif dari petani responden yang ingin melakukan perjalanan wisata. Misalnya, perjalanan wisata bersama Gereja yang biasanya di lakukan setahun sekali. Karena keseluruhan petani responden beragama Kristen, maka responden melakukan kegiatan sosial kemasyarakatan dengan beribadah ke Gereja, seminggu sekali.
Sebagian petani responden mengikuti organisasi kerukunan keluarga/arisan keluarga yang biasanya dilakukan sebulan sekali, dan seluruh petani responden juga mengikuti persatian/partisipasi kedukaan di masingmasing lingkungan tempat tinggal.

Aspek sosial lain seperti akses informasi dan hiburan dan akses terhadap media informasi dan komunikasi juga dapat menjadi bagian dalam mengukur kesejahteraan masyarakat. Petani responden dalam era yang semakin modern juga ikut berkembang dalam hal media komunikasi dan informasi, karena petani responden sebagian besar memiliki alat komunikasi, namun tidak terlalu canggih yang mampu mengakses internet dengan baik dan cepat, alat komunikasi yang di miliki petani hanya untuk berkomunikasi via telepon dan sms.

Hasil analisis dari 8 indikator kesejahteraan menunjukkan bahwa indikator kependudukan, serta kessehatan gizi memiliki presentase yang hampir sama yaitu $13.42 \%$ dan $113.63 \%$. begitu juga Pendidikan dan taraf pola konsumsi yakni $11.54 \%$ dan $11.62 \%$. Indikator kesejahteraan paling tinggi pada petani di perumahan pengungsi di Kelurahan Pandu Kecamatan Bunaken Kota Manado yaitu pada perumahan dan lingkungan yang ditunjukkan dengan nilai presentase sebesar $14.12 \%$. Sementara indikator yang masih memberikan kontribusi rendah terhadap kesejahteraan petani di perumahan pengungsi pada indikator kemiskinan $(10.43 \%)$.

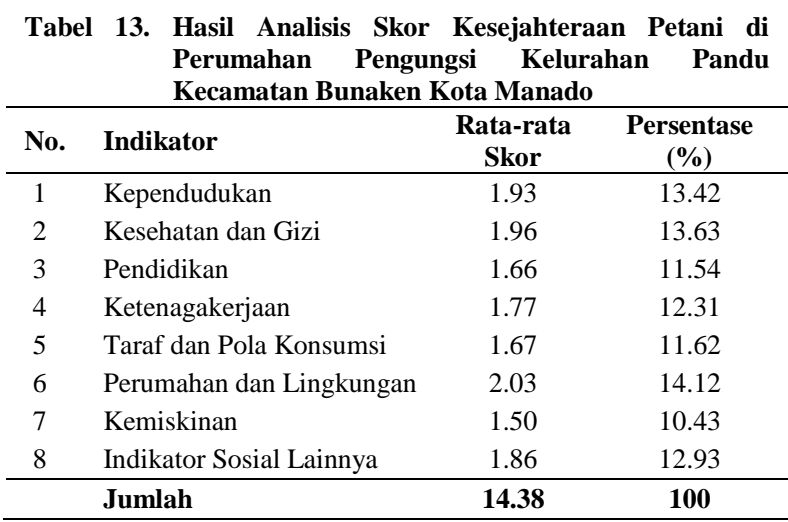

Tabel 13 menunjukkan bahwa petani di perumahan pengungsi di Kelurahan Pandu Kecamatan Bunaken Kota Manado tergolong dalam kategori tingkat kesejahteraan yang 
belum sejahtera. Petani yang tergolong pada tingkat kesejahteraan yang sedang hingga tinggi adalah petani yang mempunyai pekerjaan sampingan di luar usaha tani. Hal ini ditunjukkan juga bahwa masyarakat yang dominan di perumahan pengsungsi tersebut mempunyai pekerjaan di luar petani yakni sebagai wiraswasta, tukang dan lain di luar sebagai petani.

\section{KESIMPULAN DAN SARAN}

\section{Kesimpulan}

Kondisi sosial ekonomi dan tingkat kesejahteraan petani di perumahan pengungsi Kelurahan Pandu Kecamatan Bunaken Kota Manado tergolong dalam kriteria belum sejahtera berdasarkan indikator tingkat kesejahteraan. Hal ini di lihat dari delapan indikator dimana pendapatan dan pengeluaran yang hanya dapat memenuhi kebutuhan pokok sehari-hari diluar kebutuhan lainnya. Secara umum taraf hidup petani di perumahan pengungsi belum sejahtera.

\section{Saran}

Berdasarkan hasil penelitian yang telah disimpulkan, dapatlah disarankan petani di perumahan pengungsi mengembangkan usahataninya ditambah dengan usaha lain, baik dalam usaha tani maupun luar usaha tani untuk meningkatkan taraf hidup.

Perlu perhatian pemerintah untuk peningkatan kesejahteraan masyarakat khususnya petani dengan pemberian modal maupun peningkatan ketrampilan untuk mengembangkan usahatani dan luar usahatani.

\section{DAFTAR PUSTAKA}

Arsyad, L. 2009. Pengantar Perencanaan dan Pembangunan Ekonomi Daerah. FEUI. Jakarta.

Anonim. 2005. Survei Sosial Ekonomi Nasional. Badan Pusat Statistik. Jakarta.
Anonim. 2011. Indikator Kesejahteraan Rumah Tangga 2011. BPS. Jakarta.

Ihsan, Fuad. 2005. Dasar-Dasar Kependidikan. PT Rineka Cipta. Jakarta

Nurul, Qamal. 2009. Hak Asasi Manusia dalam Negara Hukum Demokrasi. Sinar Grafika. Jakarta

Rahardja, Pratama dan Manurung. 2004. Pengantar Ilmu Ekonomi. FE IU. Jakarta

Rinawati, R. 2012. Modal sosial masyarakat dalam pembangunan hutan rakyat di Sub Das Cisadane Hulu kasus di areal DAS Mikro Sub DAS Cisadane Hulu. Program Pascasarjana. Institut Pertanian Bogor. Bogor.

Rojas, M. 2004. Well being the complexity of poverty : a subjective well being approach. Departement of economic Universidad de las America. Mexico

Salim, A. 2002. Perubahan Sosial. Tiara Wacana. Yogyakarta.

Siswono, Y, Husodo., Bungaran Saragih., H.S. Dilon., Muslimin Nasution. 2004. Pertanian Mandiri. Penebar Swadaya. Jakarta

Soekanto, Soejono. 2007. Sosiologi Suatu Pengantar. Raja. Grafindo. Jakarta

Sri Sumekti. 2013. Studi tetang Integrasi Wanita di Kalangan Masyarakat Kota. Fakultas Pasca Sarjana, UGM. Yogyakarta

Suandi. 2007. Modal Sosial dan Kesejahteraan Ekonomi Keluarga di Daerah Perdesaan Provinsi Jambi. Program Pasca Sarjana Institut Pertanian Bogor.

Suprapto. 2013. Metodologi Penelitian dan Ilmu-ilmu Pengetahuan. Bentang Pustaka. Bandung 
Ventje, Rantung. 2016. Ekologi Manusia Teori Struktur Masyarakat. Universitas Sam Ratulangi Manado. Manado
Zunaidi, Muhammad. 2003. Kehidupan Sosial Ekonomi Pedagang di Pasar Tradisional Pasca Relokasi dan Pembangunan Pasar Modern. Vol. 3. No. 1. 